\title{
STUDI IN VITRO POTENSI ANTIOKSIDAN DAN AKTIVITAS ANTIDIABETES FRAKSI ETIL ASETAT BUAH PARIJOTO (Medinilla speciosa $\mathrm{B}$. )
}

\section{Study in Vitro of Antioxidant Potency and Antidiabetic Activity of Ethyl Acetate Fraction of Parijoto Fruit (Medinilla speciosa B.)}

\author{
Rissa Vifta $^{\left.1^{*}\right)}$, Wilantika ${ }^{2)}$, Yustisia Dian Advistasari' ${ }^{2)}$ \\ 1)2)Department of Pharmacology and Clinical Pharmacy, Faculty of Pharmacy, \\ Wahid Hasyim University, Jl. Menoreh Tengah X/22 Sampangan Semarang, Indonesia \\ *e-mail: rissalailavifta@unw.ac.id
}

\begin{abstract}
Parijoto fruit (Medinilla speciosa B.) contains flavonoid which is one of the phenolic groups compound. Flavonoids has biological activities as anti free radical and antioxidants. The aim of this research was to evaluate the antioxidant and antidiabeticantioxidant and antidiabetic potency of ethyl acetate fraction of $\underline{M}$. speciosa extracts. Evaluation of antioxidant activity was carried out by in vitro assay using the ABTS method (2,2 azinobis (3-ethylbenzotiazolin) -6-sulfonic acid), while the antidiabetic assay was carried out by using the Nelson-Somogyi method. Research began with the process of determination, extraction, fractionation, and continued by examination of each variable. The parameters of antioxidant activity was determined by $I C_{50}$ values, while antidiabetic activity was measured by a percentage of decreasing of glucose levels. The results of antioxidant activity showed that ethyl acetate fraction of $\underline{M}$. speciosa had antioxidant activity with an $I C_{50}$ value of 4,246 ppm with a very strong category. In line with these results, ethyl acetate fraction of $\underline{M}$. speciosa had reduced glucose levels with an optimum decrease of $50.21 \%$ at a concentration of 40 ppm.
\end{abstract}

Keywords: Parijoto, flavonoids, antioxidant, antidiabetic, ABTS, Nelson-Somogyi

\begin{abstract}
ABSTRAK
Buah parijoto (Medinilla speciosa B.) mengandung senyawa aktif flavonoid yang merupakan salah satu golongan fenolik. Flavonoid memiliki aktivitas biologis sebagai antiradikal bebas dan antioksidan. Penelitian dilakukan untuk mengetahui kemampuan fraksi etil asetat $\underline{M}$. speciosa sebagai antioksidan dan antidiabetes. Pengujian aktivitas antioksidan dilakukan secara in vitro dengan metode ABTS (2,2 azinobis (3-etilbenzotiazolin)-6-asam sulfonat), sedangkan uji antidiabetes dilakukan menggunakan metode Nelson-Somogyi. Penelitian diawali dengan proses determinasi, ekstraksi, fraksinasi, dan dilanjutkan dengan pengujian pada masing-masing variabel. Parameter aktivitas antioksidan diwujudkan dengan nilai $\mathrm{IC}_{50}$, sedangkan aktivitas antidiabetes diukur dengan persen penurunan kadar glukosa. Hasil pengujian aktivitas antioksidan menunjukkan bahwa fraksi etil asetat memiliki aktivitas antioksidan dengan nilai $\mathrm{IC}_{50}$ sebesar $4.14 \pm 0.08 \mathrm{ppm}$ dengan kategori sangat kuat. Sejalan dengan hasil tersebut, fraksi etil asetat buah parijoto $(\underline{M}$. speciosa) memilili kemampuan dalam menurunkan kadar glukosa dengan penurunan secara optimal sebesar $50.21 \pm 0.47 \%$ pada konsentrasi $40 \mathrm{ppm}$.
\end{abstract}

Kata kunci: Parijoto, flavonoid, antioksidan, antidiabetes, ABTS, Nelson-Somogyi 


\section{PENDAHULUAN}

Famili Melastomataceae memiliki beberapa spesies yang dilaporkan mempunyai aktivitas antioksidan tinggi, beberapa diantaranya adalah Melastoma malabathricum dan Osbeckia stellate (Balamurugan et al., 2014, Das et al., 2013). Spesies lain yang mulai mendapatkan perhatian dari kalangan peneliti adalah M. speciosa. yang merupakan tanaman khas lereng pegunungan Muria Desa Colo Kabupaten Kudus. Buah parijoto dipercaya secara empiris memiliki akivitas sebagai antioksidan serta banyak dimanfaatkan masyarakat sekitar sebagai penyubur kandungan (Wibowo dkk. 2012).

Antioksidan merupakan salah satu cara untuk mengatasi masalah radikal bebas dimana antioksidan mampu menghambat proses oksidasi yang dilakukan dengan mengikat radikal bebas dan molekul yang sangat reaktif sehingga kerusakan sel akan dihambat (Tirzitis \& Bartosz, 2010). Antioksidan terbagi menjadi antioksidan enzimatis dan non enzimatis. Antioksidan enzimatis antara lain superoksida dismutase (SOD), glutation peroksidase (GPx), dan katalase, sedangkan antioksidan non-enzimatis antara lain vitamin E, vitamin C, beta karoten yang diperoleh dari tanaman (Nisma dkk., 2010).

Penelitian yang dilakukan oleh Rudianto \& Megawati (2017) menyebutkan bahwa buah parijoto ( $M$. speciosa) mengandung senyawa aktif yang mampu menangkal radikal bebas serta memiliki aktivitas penurun kadar glukosa yang baik. Senyawa aktif pada buah parijoto ( $M$. speciosa) yang dipercaya mampu menangkal radikal bebas adalah flavonoid. Flavonoid berperan sebagai agen pereduksi, donor hidrogen, penghambat oksidasi, serta pengkhelat logam. Beberapa penelitian lain telah membuktikan bahwa flavonoid berperan aktif sebagai agen antioksidan dan aktivitas biologis lainnya (Tapas et al., 2008). Adanya senyawa flavonoid dalam buah parijoto berperan penting dalam aktivitasnya sebagai antioksidan maupun antidiabetes.

Pengukuran aktivitas antioksidan dapat dilakukan menggunakan beberapa metode yang salah satunya adalah metode ABTS (2,2 azinobis (3-etilbenzotiazolin)-6-asam sulfonat). ABTS merupakan metode yang lebih mudah diaplikasikan, sederhana, serta fleksibel dalam mengukur aktivitas antioksidan yang bersifat hidrofilik maupun lipofilik dalam ekstrak makanan dan cairan (Apak et al., 2007). Mekanisme ABTS diawali dengan pembentukan radikal antara garam ABTS dengan oksidator kalium permanganat atau kalium persulfat. Pengukuran absorbansi ABTS dilakukan pada panjang gelombang spesifik $734 \mathrm{~nm}$ (Shalaby \& Shanab, 2013).

Pengujian aktivitas penurunan kadar glukosa secara in vitro dilakukan menggunakan metode Nelson-Somogyi. Metode Nelson-Somogyi termasuk sederhana yang tidak melibatkan adanya proses enzimatis. Prinsip metode Nelson-Somogyi adalah reaksi oksidasi antara reagen Nelson dan glukosa yang kemudian dapat membentuk senyawa kompleks setelah penambahan reagen arsenomolibdat. Senyawa kompleks yang terbentuk diukur absorbansinya menggunakan spektrofotometer UV-Vis. Absorbansi yang terukur sebanding dengan jumlah glukosa yang terikat (Razak dkk., 2012).

Penelitian dilakukan untuk mengkaji potensi antioksidan dan aktivitas antidiabetes fraksi etil asetat buah parijoto serta mengetahui korelasinya. Pengukuran daya antioksidan dengan metode ABTS (2,2 azinobis (3-etilbenzotiazolin)-6-asam sulfonat) diharapkan memberikan hasil yang spesifik pada pengujian. Aktivitas penurunan kadar glukosa dapat memberikan kajian awal pemanfaatan buah parijoto (M. speciosa) sebagai kandidat terapetik antidiabetes. 


\section{METODE}

\section{Waktu dan Tempat Penelitian}

Penelitian dilaksanakan dalam dua tahapan, yakni tahap skrining atau identifikasi senyawa aktif serta pengujian aktivitas fraksi etil asetat. Tahap identifikasi senyawa aktif dilaksanakan di laboratorium fitokimia, sedangkan tahap pengujian aktivitas antioksidan dan antidiabetes fraksi etil asetat dilaksanakan di Laboratorium Instrumen Universitas Ngudi Waluyo.

\section{Alat dan Bahan}

Alat yang digunakan antara lain, peralatan gelas standar, Eppendorf Reference $200 \mu \mathrm{L}$, neraca analitik and GR-300, rotary evaporator Ryela N-1000, dan waterbath Eyela SB-1000, tabung reaksi, mikropipet, mikropipet Socorex Swiss $1000 \mu \mathrm{L}$, spatula, vial, dan spektrofotometer UV-Vis Shimadzu UV Mini 1240.

Bahan utama yang digunakan adalah buah parijoto yang diperoleh dari Desa Colo Kecamatan Dawe Kabupaten Kudus Jawa Tengah diambil pada puncak masa panen bulan Maret tahun 2018, serta beberapa reagen kimia yang meliputi serbuk glukosa anhidrat, Silika $\mathrm{GF}_{254}, \mathrm{Ka}$ Na-Tartrat, $\mathrm{NaHCO}_{3}$, natrium sulfat anhidrat, $\mathrm{CuSO}_{4} \cdot 2 \mathrm{H}_{2} \mathrm{O}$, amonium heptamolibdat, $\mathrm{Na}_{2} \mathrm{HAsO}_{4} .7 \mathrm{H}_{2} \mathrm{O}$, amoniak 25\%, ABTS (2,2 azinobis (3-etilbenzotiazolin)-6-asam sulfonat), $\mathrm{K}_{2} \mathrm{SO}_{4}$, $\mathrm{n}$ heksan, etil asetat, n-butanol, asam asetat glasial, etanol 96\%, dari Merck dan akuades.

\section{Fraksinasi Ekstrak Buah Parijoto}

Pembuatan fraksi etil asetat diawali dengan proses ekstraksi buah parijoto dengan pelarut etanol 96\%. Sebanyak 200 gram serbuk buah parijoto dimaserasi dengan pelarut etanol (1:10) selama dua hari, dilanjutkan remaserasi satu hari. Filtrat yang terkumpul diuapkan menggunakan rotary evaporator pada suhu $80^{\circ} \mathrm{C}$ hingga diperoleh ekstrak kental dan berbobot konstan. Fraksinasi dilakukan dengan melarutkan 10 gram ekstrak dengan 50 ml akuades dan dimasukkan dalam corong pisah dan dipartisi menggunakan tiga pelarut yang berbeda tingkat kepolarannya. Pada tahap awal fraksinasi dilakukan dengan menambahkan pelarut $n$-heksan (1:1) dan dipisahkan sampai fase n-heksan jernih. Fraksinasi dilanjutkan dengan pelarut etil asetat (1:1), fraksi yang diperoleh ditampung dan dipekatkan dengan waterbath dan dihitung rendemennya.

\section{Skrining Fitokimia}

Skrining fitokimia dilakukan secara kualitatif dengan uji tabung dan semi kuantitatif dengan kromatografi lapis tipis (KLT). Uji tabung dilakukan untuk mengidentifikasi adanya senyawa flavonoid, alkaloid, saponin, dan tanin dalam buah parijoto. KLT menggunakan fase diam silika $\mathrm{GF}_{254}$ dan fase gerak n-butanol:asam asetat:akuades (3:1:1) hasil optimasi.

\section{Uji Aktivitas Antioksidan dengan Metode ABTS (Shalaby \& Shanab, 2013)}

Penentuan aktivitas antioksidan diawali dengan penentuan panjang gelombang maksimum larutan ABTS pada rentang panjang gelombang 414-734 nm dan dilanjutkan dengan penentuan waktu operasional. Fraksi etil asetat buah parijoto sebanyak $50 \mathrm{mg}$ dilarutkan dalam metanol p.a. add $50 \mathrm{ml}$ dalam labu ukur sehingga diperoleh larutan stok $1000 \mathrm{ppm}$ dan kemudian dibuat seri konsentrasi 2 ppm, 4 ppm, 6 ppm, 8 ppm dan 10 ppm. Masing-masing konsentrasi ditambahkan larutan ABTS untuk selanjutnya diukur absorbansinya pada panjang gelombang yang telah ditentukan. Aktivitas antioksidan dihitung menggunakan persamaan: 


$$
\% \text { Penangkap radikal }=\frac{A c-A s}{A s} \times 100 \%
$$

Keterangan :

Ac $\quad=$ Absorbansi kontrol (sebelum perlakuan)

As $\quad=$ Absorbansi sampel (setelah penambahan fraksi etil asetat)

Perhitungan nilai $\mathrm{IC}_{50}$ dilakukan secara regresi dimana x sebagai konsentrasi (ppm) dan y sebagai persentasi aktivitas (\%). Nilai $I C_{50}$ didapatkan dari x setelah mengganti y dengan 50.

\section{Uji Aktivitas Antidiabetes dengan Nelson-Somogyi (Al-kayyis \& Susanti, 2016)}

Penentuan aktivitas antidiabetes diawali dengan penentuan panjang gelombang maksimum, waktu operasional, serta pembuatan kurva baku glukosa. Fraksi etil asetat buah parijoto masing-masing dibuat seri konsentrasi 10, 20 30, 40, 50, dan 60 ppm. Masing-masing seri larutan diambil $3 \mathrm{ml}$ dimasukkan dalam tabung reaksi, ditambahkan dengan $3 \mathrm{ml}$ baku glukosa konsentrasi 80 ppm. Selanjutnya, diambil $1 \mathrm{ml}$ dari larutan, dimasukkan ke dalam labu takar $10 \mathrm{ml}$, dan ditambah $1 \mathrm{ml}$ reagen Nelson. Selanjutnya, ditutup dengan kapas dan dipanaskan di atas air mendidih selama 10 menit. Larutan didinginkan selama 5 menit, ditambah $1 \mathrm{ml}$ reagen arsenomolibdat, dan ditambah akuades sampai tanda batas, dikocok dan didiamkan pada waktu operasional. Hasilnya dibaca dengan spektrofotometri UV-Vis pada panjang gelombang maksimal. Aktivitas penurunan kadar glukosa dihitung menggunakan persamaan.

$$
\% \text { Penurunan Kadar }=\frac{\text { Kadar }(\text { Baku })-\text { Kadar }(\text { Sampel })}{\text { Kadar }(\text { Baku })} \times 100 \%
$$

Kadar baku dan sampel diperoleh melalui perhitungan menggunakan persamaan regresi linier yang telah ditetapkan melalui pembuatan kurva standar.

\section{HASIL DAN PEMBAHASAN}

Hasil determinasi buah parijoto yang dilakukan di laboratorium Ekologi dan Biosistematik Universitas Diponegoro menunjukkan bahwa spesimen yang digunakan merupakan buah tanaman M. speciosa yang berasal famili Melastomaceae. Hasil fraksinasi ekstrak etanol buah parijoto memperoleh rendemen fraksi sebesar 12,91\%. Penapisan fitokimia secara kualitatif pada fraksi etil asetat buah parijoto menunjukkan hasil positif adanya kandungan flavonoid, alkaloid, tanin, dan saponin sesuai yang ditunjukkan pada Tabel 1.

Tabel 1. Hasil skrining kualitatif ekstrak dan fraksi etil asetat buah parijoto

\begin{tabular}{lcc}
\hline \multicolumn{1}{c}{ Jenis uji } & Ekstrak etanol & Fraksi etil asetat \\
\hline Flavonoid & + & + \\
Alkaloid & + & + \\
Tanin & + & + \\
Saponin & + & + \\
\hline
\end{tabular}

Penapisan fitokimia dilanjutkan dengan metode KLT yang bertujuan mempertegas adanya kandungan flavonoid pada fraksi etil asetat buah parijoto. KLT merupakan metode pemisahan yang sederhana, cepat, murah serta efektif, dan dapat diaplikasikan pada berbagai sampel bahan alam (Skorek et al., 2016). Pemisahan senyawa dengan KLT dilakukan dengan fase diam silika 
gel $\mathrm{GF}_{254}$ dan fase gerak n-butanol:akuades:asam asetat (3:1:1). Fase gerak yang digunakan bersifat sangat polar sehingga dapat memisahkan senyawa secara optimal.

Tabel 2. Hasil KLT flavonoid ekstrak dan fraksi etil asetat buah parijoto

\begin{tabular}{lccc}
\hline Sampel & $\begin{array}{c}\text { Warna spot } \\
(\text { Sinar UV254 })\end{array}$ & Rf & $\begin{array}{c}\text { Visualisasi } \\
\text { (Uap Amoniak) }\end{array}$ \\
\hline Rutin & Cokelat & 0.98 & Kuning kehijauan \\
Ekstrak & Cokelat & 0.88 & Kuning kehijauan \\
Fraksi Etil Asetat & Cokelat & 0.91 & Kuning kehijauan \\
\hline
\end{tabular}

Hasil KLT pada Tabel 2 menunjukkan adanya senyawa flavonoid pada fraksi etil asetat buah parijoto yang ditandai dengan terbentuknya spot berwarna kuning kehijauan setelah disemprot dengan uap amoniak. Kandungan senyawa flavonoid pada fraksi etil asetat buah parijoto diduga memiliki aktivitas sebagai antioksidan dan antidiabetes. Disebutkan bahwa flavonoid terdapat pada sebagian besar bagian tanaman baik pada buah, daun, biji, dan bunga pada tanaman serta memiliki efek terapetik sebagai antioksidan, antijamur, antiinflamatori, antikanker, dan beberapa aktivitas lainnya (Itoh et al. 2009, Proestos \& Varzakas, 2017)

Uji aktivitas antioksidan fraksi etil asetat buah parijoto (M. speciosa) dilakukan dengan metode ABTS. Pada umumnya, metode ABTS digunakan sebagai penentu aktivitas antioksidan dengan pembanding vitamin $\mathrm{C}$ atau vitamin $\mathrm{E}$ yang dikondisikan pada fase air. Kemampuan penangkal radilkal bebas pada fraksi etil asetat buah parijoto (M. speciosa) ditandai dengan berkurangnya intensitas warna biru dari larutan ABTS yang telah ditambahkan dalam sampel (Shalaby \& Shanab, 2013).

Tabel 3. Aktivitas Antioksidan Fraksi Etil Asetat Buah Parijoto

\begin{tabular}{cccccccccc}
\hline \multirow{2}{*}{ No } & Konsentrasi (ppm) & \multicolumn{5}{c}{ Absorbansi } & \multicolumn{7}{c}{ Aktivitas Antioksidan } & IC50 (ppm) & Kategori \\
\cline { 2 - 7 } & & R1 & R2 & R3 & R1 & R2 & R3 & (Rata-rata \pm SD) & \\
\hline 1 & 2 & 0.338 & 0.348 & 0.343 & 35.12 & 33.21 & 34.17 & & Sangat Kuat \\
2 & 4 & 0.288 & 0.26 & 0.271 & 44.72 & 50.1 & 47.98 & & \\
3 & 6 & 0.185 & 0.185 & 0.183 & 64.49 & 64.49 & 64.88 & $4.14 \pm 0.08$ & \\
4 & 8 & 0.131 & 0.126 & 0.125 & 74.86 & 75.82 & 76.01 & \\
5 & 10 & 0.084 & 0.086 & 0.078 & 83.88 & 83.49 & 85.03 & & \\
\hline
\end{tabular}

Keterangan :

$\mathrm{R} 1=$ Replikasi/Pengulangan 1

R2 = Replikasi/Pengulangan 2

R3 = Replikasi/Pengulangan 3

Hasil pengujian aktivitas antioksidan yang pada Tabel 3 menunjukkan bahwa fraksi etil asetat buah parijoto memiliki kemampuan dalam menghambat pembentukan radikal bebas ABTS ditandai dengan penurunan nilai absorbansi seiring kenaikan konsentrasinya. Nilai $\mathrm{IC}_{50}$ rata-rata yang dihasilkan sebesar $4.14 \pm 0.08 \mathrm{ppm}$ dengan kategori antioksidan sangat kuat. $\mathrm{IC}_{50}$ menggambarkan kemampuan antioksidan dalam meredam $50 \%$ radikal bebas (Tirzitis \& Bartosz, 2010).

Prinsip pengujian dengan metode ABTS adalah mengukur daya peredaman antioksidan terhadap radikal bebas ABTS. Pengujian ABTS berdasarkan pada generasi ABTS.+ biru/hijau yang dapat direduksi oleh antioksidan. Flavonoid bereaksi dengan kation ABTS ${ }^{+}$membentuk ABTS radikal yang lebih stabil atau senyawa bukan radikal. Dalam hal ini terjadi oksidasi radikal yang mana intensitas warna berkurang karena direduksi oleh molekul ABTS dan terjadi perubahan warna menjadi hijau-biru. Antioksidan seperti flavonoid menekan pembentukan 
warna karena terjadi reduksi ABTS.+ sehingga terjadi penurunan absorbansi (Floegel et al., 2011).

Kenaikan konsentrasi fraksi etil asetat buah parijoto (M. speciosa) berbanding terbalik dengan nilai absorbansinya. Semakin tinggi konsentrasi, nilai absorbansi semakin kecil, sehingga persen aktivitas antioksidan yang dihasilkan semakin meningkat seperti yang ditunjukkan pada Gambar 1. Kurva hubungan antara konsentrasi dan aktivitas antioksidan secara regresi linier digunakan untuk menentukan nilai $\mathrm{IC}_{50}$ sesuai dengan persamaan yang telah diperoleh.

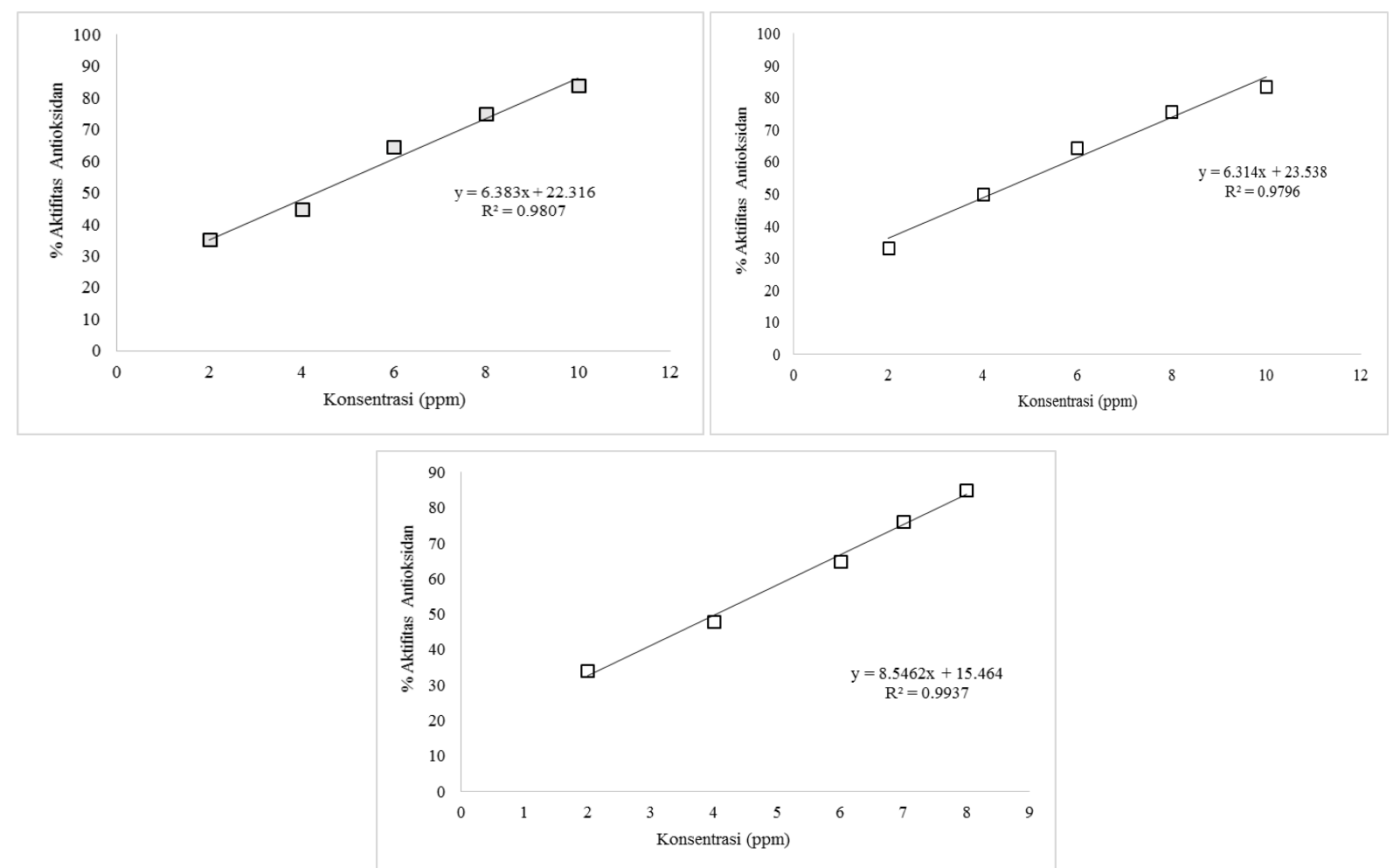

Gambar 1. Kurva hubungan antara konsentrasi dengan aktivitas antioksidan fraksi etil asetat buah parijoto (M. speciosa)

Fraksi etil asetat buah parijoto mengandung senyawa flavonoid yang merupakan salah satu golongan senyawa fenolik, dimana senyawa golongan tersebut memiliki kemampuan dalam menangkap radikal bebas dengan cara mendonorkan atom hidrogen pada senyawa radikalnya (Melichacova et al., 2010). Senyawa-senyawa fitokimia yang mudah larut dalam pelarut polar maupun semi polar seperti flavonoid, tanin, sterol, serta antrakuinon telah terbukti memiliki aktivitas sebagai penangkap radikal bebas dan antioksidan (Shalaby \& Shanab, 2013; Ali et al., 2018).

Aktivitas penurunan kadar glukosa fraksi etil asetat buah parijoto dilakukan secara in vitro menggunakan metode Nelson-Somogyi. Metode Nelson-Somogyi mudah diterapkan pada pengukuran sampel yang mengandung glukosa dengan hasil lebih spesifik serta faktor pengganggu lebih mudah dikendalikan. Konsentrasi fraksi etil asetat yang digunakan adalah 10, 20, 30, 40, 50, dan 60 ppm dengan kadar baku glukosa sebelum perlakuan sebesar $44.74 \mathrm{ppm}$. Hasil uji aktivitas antidiabetes fraksi etil asetat buah parijoto disajikan pada Tabel 4. 
Tabel 4. Aktivitas antidiabetes fraksi etil asetat buah parijoto

\begin{tabular}{lcccc}
\hline \multirow{2}{*}{ Konsentrasi (ppm) } & \multicolumn{3}{c}{ Penurunan Kadar (\%) } \\
\cline { 2 - 4 } & Replikasi 1 & Replikasi 2 & Replikasi 3 & \\
\hline Kadar Baku & 44,74 & 44,74 & 44,74 & \\
FEA 10 & 45,57 & 45,31 & 45,66 & $45,51 \pm 0,18$ \\
FEA 20 & 44,87 & 44,62 & 44,79 & $44,76 \pm 0,13$ \\
FEA 30 & 46,95 & 46,71 & 47,06 & $46,91 \pm 0,18$ \\
FEA 40 & 50,57 & 49,68 & 50,38 & $50,21 \pm 0,47$ \\
FEA 50 & 46,26 & 46,19 & 46,36 & $46,27 \pm 0,09$ \\
FEA 60 & 41,41 & 40,60 & 39,55 & $40,52 \pm 0,93$ \\
\hline
\end{tabular}

Tabel 4 menunjukkan bahwa konsentrasi 40 ppm fraksi etil asetat mampu menurunkan secara optimal kadar glukosa dengan persentase $50,21 \pm 0,47 \%$. Aktivitas penurunan glukosa pada fraksi etil asetat disebabkan adanya gugus hidroksi $(-\mathrm{OH})$ pada flavonoid yang terkandung dalam fraksi etil asetat buah parijoto. Gugus hidroksi pada flavonoid bereaksi dengan glukosa membentuk kompleks flavonoid-glukosa seperti yang ditunjukkan pada Gambar 2. Selanjutnya, sisa glukosa yang tidak diikat oleh flavonoid, selanjutnya bereaksi dengan reagen Nelson dan arsenomolibdat sampai terbentuk komplek dan penurunan kadar glukosa dapat terukur.

Prinsip kerja metode Nelson-Somogyi yaitu tereduksinya jumlah endapan kupro-oksida yang bereaksi dengan arsenomolibdat menjadi kompleks molybdine blue berwarna biru yang dapat terukur dengan spektrofotometer UV-Vis. Intensitas warna yang terbentuk menunjukkan banyaknya gula pereduksi yang terdapat dalam sampel, hal tersebut karena konsentrasi arsenomolibdat yang tereduksi sebanding dengan konsentrasi tembaga (I) oksida $\left(\mathrm{Cu}_{2} \mathrm{O}\right)$ atau kupro-oksida, sedangkan konsentrasi $\mathrm{Cu}_{2} \mathrm{O}$ sebanding dengan konsentrasi gula pereduksi (Alkayyis \& Susanti, 2016).

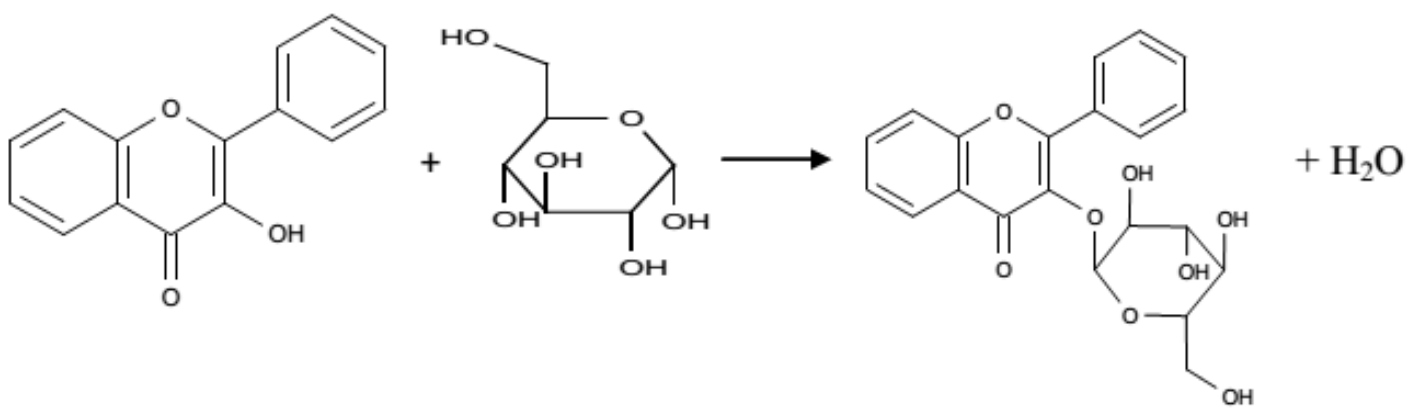

Gambar 2. Reaksi pembentukan kompleks flavonoid-glukosa

Reagen Nelson bereaksi dengan sisa glukosa membentuk asam D-glukonat dan endapan kupro-oksida berwarna merah bata. Jumlah kupro-oksida yang terbentuk ekuivalen dengan jumlah gula pereduksi yang ada. Ion kupri $\left(\mathrm{Cu}^{2+}\right)$ dari reagen Nelson akan mengoksidasi glukosa menjadi asam glukonat dan membentuk endapan kupro-oksida $\left(\mathrm{Cu}_{2} \mathrm{O}\right)$, sehingga jumlah kupro-oksida ekuivalen dengan jumlah glukosa yang ada. Selanjutnya endapan merah bata kupro-oksida ditambahkan dengan reagen arsenomolibdat akan membentuk molibdenum berwarna biru kehijauan (Razak dkk., 2012; Al-kayyis \& Susanti, 2016). Reaksi yang terjadi antara reagen Nelson dengan glukosa serta pembentukan kompleks molybdine blue dijabarkan pada Gambar 3. 


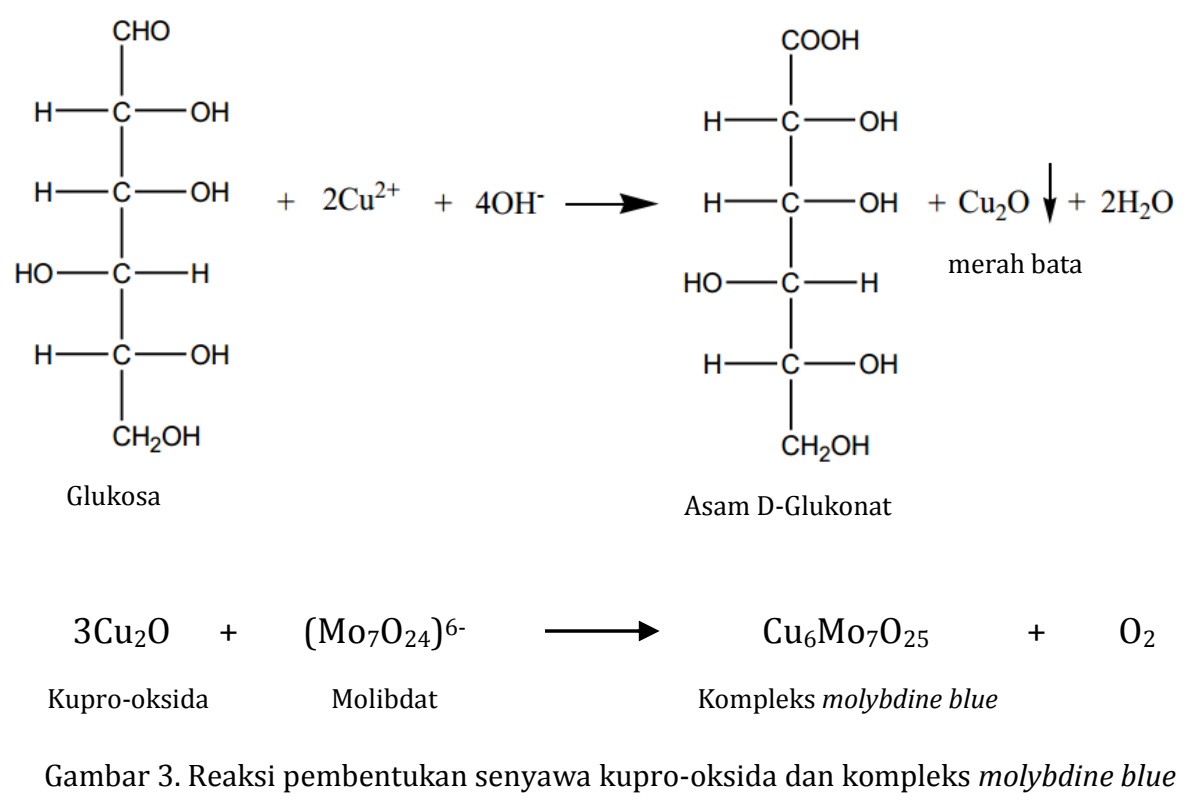

Aktivitas penurunan kadar glukosa yang ditunjukkan oleh Gambar 4 menunjukkan bahwa kenaikan konsentrasi fraksi memberikan pengaruh terhadap penurunan kadar glukosa. Pada konsentrasi sampel paling kecil memberikan absorbansi yang besar sehingga persen penurunan glukosanya kecil. Semakin tinggi konsentrasi fraksi yang diberikan, semakin banyak glukosa yang terikat dan sisa glukosa semakin sedikit sehingga memberikan penurunan kadar glukosa yang besar. Setelah mencapai konsentrasi maksimum, absorbansi sampel akan kembali naik dan memberikan penurunan glukosa yang kecil.

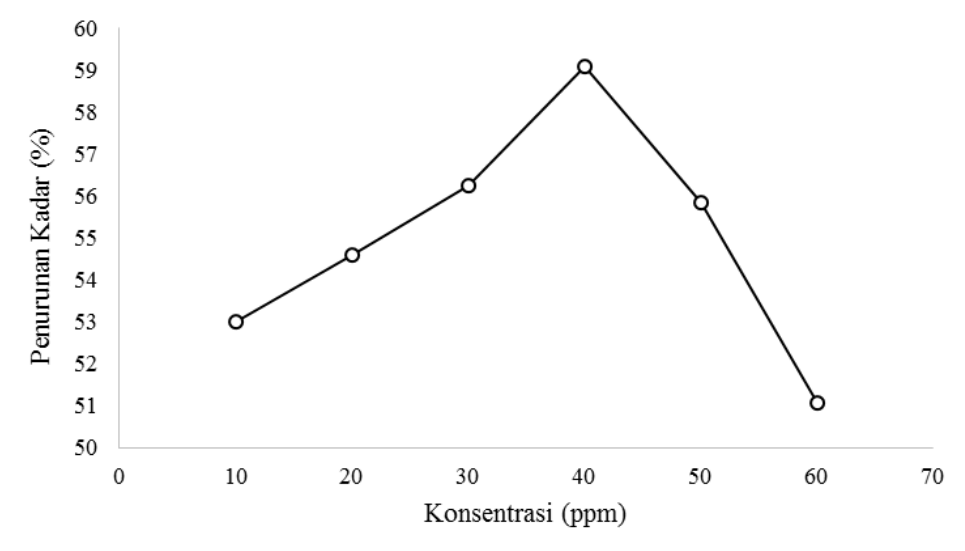

Gambar 4. Pengaruh fraksi etil asetat buah parijoto (Medinilla speciosa B.) terhadap penurunan kadar glukosa

Aktivitas antioksidan dan antidiabetes fraksi etil asetat buah parijoto memberikan hasil yang sejalan dalam menghambat pembentukan radikal bebas terutama dalam menurunkan stres oksidatif yang dapat menurunkan sekresi insulin (Nicolle et al., 2011, Sarian et al., 2017). Korelasi hubungan antara aktivitas antioksidan dan antidiabetes fraksi etil asetat buah parijoto ditunjukkan oleh Tabel 5. Nilai korelasi diperoleh berdasarkan nilai linieritas kurva regresi antara persen aktivitas antioksidan dan antidiabetes. Nilai korelasi yang diperoleh sebesar 0,944 atau mendekati 1. Dengan demikian dapat disimpulkan bahwa terdapat hubungan atau korelasi 
yang sejalan antara aktivitas antioksidan dengan antidiabetes pada fraksi etil asetat buah parijoto.

Antioksidan memiliki kemampuan dalam meningkatkan kerja insulin. Beberapa penelitian menunjukkan bahwa flavonoid sangat berpotensi sebagai antioksidan yang berperan aktif dalam melawan proses oksidasi yang dapat mempengaruhi metabolisme glukosa, sehingga menimbulkan efek hiperglikemia. Flavonoid berperan aktif sebagai penangkal radikal yang dapat memicu terjadinya Diabetes Mellitus (DM) tipe II (Sarian et al., 2017; Widowati, 2010). Beberapa tanaman dilaporkan memiliki kandungan flavonoid yang berperan sebagai antioksidan dan antidiabetes. Tumbuhan mempelas (Tetracera indica) dan semanggi (Tetracera scandens) yang merupakan famili Dilleniaceae terbukti mengandung flavonoid dan secara empiris dimanfaatkan oleh masyarakat sebagai obat diabetes mellitus. Selain itu, isoflavon yang berasal dari ekstrak kacang kedelai mampu memperbaiki resistensi insulin serta penurunan kadar glukosa (Proestos \& Varzakas, 2017).

\section{KESIMPULAN}

Fraksi etil asetat buah parijoto (M. speciosa) memiliki aktivitas antioksidan dengan nilai $\mathrm{IC}_{50}$ sebesar 4,14 $\pm 0,08 \mathrm{ppm}$ dengan kategori sangat kuat. Sejalan dengan hasil tersebut, fraksi etil asetat buah parijoto juga memilili kemampuan dalam menurunkan kadar glukosa dengan penurunan secara optimal sebesar $50,21 \pm 0,47 \%$ pada konsentrasi $40 \mathrm{ppm}$. Senyawa aktif flavonoid dalam buah parijoto (M. speciosa) memiliki kemampuan dalam menangkal radikal bebas serta berperan sebagai antioksidan dan antidiabetes.

\section{UCAPAN TERIMA KASIH}

Ucapan terima kasih disampaikan kepada Direktorat Riset dan Pengabdian Masyarakat Direktorat Jenderal Penguatan Riset dan Pengembangan Kemenristekdikti yang telah memberikan fasilitas pendanaan Hibah Penelitian Dosen Pemula (PDP) Tahun Pelaksanaan 2018 demi tercapainya penelitian ini.

\section{DAFTAR PUSTAKA}

Ali, A. M. A., El-Nour, M. E. M., \& Yagi, S. M. (2018). Total Phenolic and Flavonoid Contents and Antioxidant Activity of Ginger (Zingiber officinale Rosc.) Rhizome, Callus and Callus Treated with Some Elicitors. Journal of Genetic Engineering and Biotechnology. 16(2), pp : 677-682

Al-kayyis, H. K., \& Susanti, H. (2016). Perbandingan Metode Somogyi-Nelson dan Anthrone-Sulfat pada Penetapan Kadar Gula Pereduksi dalam Umbi Cilembu (Ipomea batatas L.). Jurnal Farmasi Sains dan Komunitas (Journal of Pharmaceutical Sciences and Community), 13(2), 81-89.

Apak, R., Güçlü, K., Demirata, B., Özyürek, M., Çelik, S. E., Bektaşoğlu, B., \& Özyurt, D. (2007). Comparative Evaluation of Various Total Antioxidant Capacity Assays Applied to Phenolic Compounds with the CUPRAC Assay. Molecules, 12(7), 1496-1547.

Balamurugan, K., Nishanthini, A., \& Mohan, V. R. (2014). Antidiabetic and Antihyperlipidaemic Activity of Ethanol Extract of Melastoma malabathricum Linn. Leaf in Alloxan Induced Diabetic Rats. Asian Pacific Journal of Tropical Biomedicine, 4, S442-S448.

Das, S. \& Coku, A. (2013). Antimicrobial and Antioxidant Activities of Osbeckia stellata Buch.-Ham. Ex D. Don (Melastomataceae) Prevalent of Darjeeling Hills. International Journal Pharmacy and Pharmaceutical Sciences, 5(2), 551-554. 
Floegel, A., Kim, D. O., Chung, S. J., Koo, S. I., \& Chun, O. K. (2011). Comparison of ABTS/DPPH Assays to Measure Antioxidant Capacity in Popular Antioxidant-rich US Foods. Journal of Food Composition and Analysis, 24(7), 1043-1048.

Itoh, A., Isoda, K., Kondoh, M., Kawase, M., Kobayashi, M., Tamesada, M., \& Yagi, K. (2009). Hepatoprotective Effect of Syringic Acid and Vanillic Acid on Concanavalin an Induced Liver Injury. Biological and Pharmaceutical Bulletin, 32(7), 1215-1219.

Melichácová, S., Timoracká, M., Bystrická, J., \& Vollmannová, A. (2010). Relation of Total Antiradical Activity and Total Polyphenol Content of Sweet Cherries (Prunus avium L.) and Tart Cherries (Prunus cerasus L.). Acta Agriculturae Slovenica, 95(1), 21.

Nicolle, E., Souard, F., Faure, P., \& Boumendjel, A. (2011). Flavonoids as Promising Lead Compounds in Type 2 Diabetes Mellitus: Molecules of Interest and Structure-Activity Relationship. Current Medicinal Chemistry, 18(17), 2661-2672.

Nisma, F., Situmorang, A., \& Fajar, M. (2010). Uji Aktivitas Antioksidan Ekstrak Etanol 70\% Bunga Rosella (Hibiscus sabdariffa L.) Berdasarkan Aktivitas SOD (Superoxyde Dismutase) dan Kadar MDA (Malonildialdehide) pada Sel Darah Merah Domba yang Mengalami Stres Oksidatif In Vitro. Farmasisains, 1(1).

Proestos, C., \& Varzakas, T. (2017). Aromatic Plants: Antioxidant Capacity and Polyphenol Characterisation. Foods, 6(4), 28.

Razak, A. R. R., Sumarni, N. K., \& Rahmat, B. (2012). Optimalisasi Hidrolisis Sukrosa Menggunakan Resin Penukar Kation Tipe Sulfonat. Natural Science: Journal of Science and Technology, 1(1).

Rudianto, R., \& Megawati, A. (2017). Pengaruh Pemberian Ekstrak Buah Parijoto (Medinilla speciosa Blume) terhadap Penurunan Kadar Glukosa Darah pada Tikus Putih. Prosiding HEFA (Health Events for All), 1(1).

Sarian, M. N., Ahmed, Q. U., So'ad, M., Zaiton, S., Alhassan, A. M., Murugesu, S., \& Latip, J. (2017). Antioxidant and Antidiabetic Effects of Flavonoids: A Structure-Activity Relationship Based Study. BioMed Research International, 2017.

Shalaby, E. A., \& Shanab, S. M. (2013). Comparison of DPPH and ABTS Assays for Determining Antioxidant Potential of Water and Methanol Extracts of Spirulina platensis. Indian Journal of GeoMarine Science. 42(5), 556-564.

Skorek, M., Jurczyk, K., Sajewicz, M., \& Kowalska, T. (2016). Thin Layer Chromatographic Identification of Flavonoids and Phenolic Acids Contained in Cosmetic Raw Materials. Journal of Liquid Chromatography \& Related Technologies, 39(5-6), 286-291.

Tapas, A. R., Sakarkar, D. M., \& Kakde, R. B. (2008). Flavonoids as Nutraceuticals: a Review. Tropical Journal of Pharmaceutical Research, 7(3), 1089-1099.

Tirzitis, G., \& Bartosz, G. (2010). Determination of Antiradical and Antioxidant Activity: Basic Principles and New Insights. Acta Biochimica Polonica, 57(1), 139-142.

Wibowo, H. A., Wasino, W., \& Setyowati, D. L. (2012). Kearifan Lokal dalam Menjaga Lingkungan Hidup (Studi Kasus Masyarakat di Desa Colo Kecamatan Dawe Kabupaten Kudus). Journal of Educational Social Studies, 1(1).

Widowati, W. (2010). Potensi Antioksidan sebagai Antidiabetes. Jurnal Kedokteran Maranatha, 7(2). 